\title{
Solid Waste Management in the Accra Metropolitan Area of Ghana
}

\author{
Zhang Ruocheng ${ }^{1 *}$, Alphonse Badolo ${ }^{2}$
}

\author{
${ }^{1}$ Research Assistant, The Center for Studies of Hong Kong, Macao and Pearl River Delta Key Research Institute of Humanities and Social \\ Science; Institute of Guangdong Hong Kong and Macao Development Studies, Sun Yat-sen University. China. \\ ${ }^{2}$ Post Graduate Student, National Research University, Higher School of Economics. Russia. \\ *Corresponding author: zhchzhan@edu.hse.ru
}

Received: 20 Oct 2020; Received in revised form: 11 Nov 2020; Accepted: 16 Nov 2020; Available online: 17 Nov 2020

\begin{abstract}
Waste management is one of the key challenges that is facing the world today. This global threat of solid waste disposal has affected Africa in many ways especially causing diseases and increasing thepoverty rate. These problems emerge mainly as a lack of strategic planning for effective SWM, poor governance, resource constraint, poor coordination and lack of proper management. In most rapidly growing cities in developing countries, the major concern issue is the inefficient solid waste collection and disposal. This research focuses on how municipal solid waste is managed by the public administration system which is the AMA of Ghana. The study, therefore, focused on existing pieces of literature and came out with these results. It was revealed that the types and sources of solid waste in the study area include, domestic waste, commercial waste, agricultural waste, industrial stemming from food waste, rubber, paper, glass, metal, farm etc., The study also revealed the major policies guiding SWM in the study area which include the Environmental Sanitation Policy of 1999 Act (1994), Act 464. Another policy is the Environmental Assessment Regulation LI 1650 which had legal support from the Environmental Protection Agency Act 490 which spelt out the Environmental Assessment Regulation (EAR). Finally, the study revealed that there is a strong relationship between poor SWM and the impact on the health of people and the cases that were observed in the study area consist of malaria, typhoid fever, skin infections, and cholera.
\end{abstract}

Keywords—solid waste, solid waste management, AMA, sustainability, Ghana.

\section{INTRODUCTION}

Waste management is one of the key challenges that is facing the world today. This problem is not only an issue for developing countries but also for developed worlds. Chazan (2002) added that SWM is a social problem in the perspective of the international construct. Thus, the problem of SWM has its root in both the developed and the developing nations as research has shown that some advanced nations are seriously facing this challenge.

According to Wilson et al. (2015), even this usage of 'waste' is still very broad, as it includes such unwanted outputs of human activity such as gases, liquids and solids as well as discharges to the three environmental receiving media of water, air and land. The UN Statistics Division uses the term' residuals' rather than 'waste' in this broad context, where they comprise one of six components of a comprehensive set of environmental statistics.
Many pieces of literature having their thought on the topic "SWM" attest that despite many efforts by various governments towards programmes designed to halt the problem of SWM, it has been noted that such programmes have failed to execute its intended goal (s). Although the developed countries have been able to design SWM technologies to curtail this bane, many pieces of research have come to the conclusion that the problems still exist. Kwawe (1995) supported this by attesting that even the invention of technology has not been able to effectively control waste generated in communities worldwide, however, it has rather degenerated the situation into a more uncontrollable mess.

According to Lyse (2003), SWM is one of the major problems facing Africa, nine out of ten cities in Africa face serious solid waste problems. MSW is not well managed in most low-income and developing countries because cities 
and municipal councils cannot deal with the rate of solid waste production. This global threat of solid waste disposal has affected Africa in many ways especially causing diseases and increasing the poverty rate. These problems emerge mainly as a lack of strategic planning for effective SWM, poor governance, resource constraint, poor coordination and lack of proper management. In most rapidly growing cities in developing countries, the major concern issue is efficient solid waste collection and disposal.

In Ghana, the issue of inefficient solid waste collection and improper disposal resulting to heaps of solid waste materials involving organic waste and rubber bags scattered everywhere and disposal sites engulfed with filth which have a detrimental health effect like cholera, malaria and typhoid to residents who live close to the dumping site (Adu-Boahen et al., 2014). According to UNCHS (1996) report, it is estimated that approximately almost half of the waste generated within most cities in low and middleincome areas, (including Ghana) are not collected. Through the process wind and poor general attitudinal behaviour exhibited by many residents and other people, the wastes usually end up on illegal dumps, on street, roadsides, open spaces and drainage systems.

An environmental health issue reported by Heller \& Catapreta (2003) demonstrates that the presence of sanitary or controlled landfill in urban areas and its implications for the health of the population that lives in its bordering area has been little investigated. Their findings continued to prove that the presence of these deposits, improper treatment of waste as a result of lack of financial constraint and logistics may draw many diverse insects and flies known as vectors to these places and facilitate the propagation of diseases from area to another with an acute health implications on the lives of many people living near and around the dumping sites.

There are rapid urbanization and high in-migration especially movement from the rural centres of Ghana to the city of Accra. Many pieces of research add that for the past four decades, the Accra metropolis has experienced overwhelming rapid urbanization thereby increasing the city's problems including SWM(GSS, 2014).

By estimate, the population of Accra in 1960 was 450000, in 1970, the population doubled and reached 1.3million in 1984 (Boadi, K. O., \& Kuitunen, M., 2003). Benneh et al., (1993), also found that due to rapid urbanization as result of population growth and improvement in socioeconomic development, the city of Accra is experiencing an uncontrollable expansion exceeding its boundaries to peripherical lands, however, the institutional capacity is limited in terms of budget allocation and logistics and this has resulted in the problem of inadequate SWM, posing health risks and burdens to many residents.

According to the EPA of Ghana's 2003 draft report on the environment, MSW is the "waste disposed of by households, hotels or motels, commercial, institutional and industrial sources. Statistics provided by the EPA shows that presently, only 55 per cent of waste in all forms generated within the area of Accra is properly collected and dumped by the AMA. In 1998, it was estimated that $765,000 \mathrm{~m}$ of solid waste and $75,000 \mathrm{~m}$ of liquid waste was generated in Accra per year.

\subsection{Objectives of the Study}

They study seeks to:

1. Examine the policies governing solid manage waste practices in the Accra Metropolitan Area of Ghana?

2. Identify the types and sources of waste as well as methods of waste disposal in the study area?

3. Examine the impacts of improper SWM on the health of people in the study area?

\section{LITERATURE REVIEW}

\subsection{Solid Waste Management}

According to Wilson et al. (2015), even this usage of 'waste' is still very broad, as it includes such unwanted outputs of human activity as gases, liquids and solids as well as discharges to the three environmental receiving media of air, water and land.

(Skenderovic et al., 2015) on the other hand, assess waste management as the process of gathering, transferring, organizing or categorizing, recycling, dumping, following, evaluating and monitoring of waste.

Chang, N. B. (2015) also defined MSWas comprisingof household waste, commercial waste, and institutional waste. Itincludes separatelycollected fractions from public service areas and private sectors,such as; garden and park waste (including cemetery waste),waste from markets.

\subsubsection{Waste Generation}

Waste generation is influenced by socio-economic development, level of industrial activities and climate. Generally, the level of economic prosperity and the size of the urban population of a particular country determines the amount of solid waste that will be generated (Bavel \& Reher, 1999).

There is a variation from region to region and from season to season in terms of municipal solid waste generation and 
also a strong link with the degree of socio-economic development and other activities. It is argued that high income countries generate more waste than low income countries. The UNESCAP(2012), added that high-income countries produce between 1.1 and 5.0 kilogram per capita per day; middle-income countries including Ghana generate between 0.52 and1.0 kilogram per capita per day, whilst low-income countries produce between 0.45 and 0.89 kilograms per capita per day.

Africa and particularly Ghana, are rich in terms of soil quality where the majority of food produced are consumed in its raw state, only a small proportion of these foods receive an added value through proper packaging. In Ghana, tuber content foods like cassava, yam, plantain etc account for the majority of solid waste generation in many households. It is estimated that the average quantity of solid waste generated in Accra per day is around One thousand five hundred tons (Anomanyo E.D. 2004). Anomanyo E.D also found that approximately two hundred tons of organic waste are directed into Accra's composting plant. Three hundred tons are left uncollected while the remaining waste accounting for about 1,000 tons are transferred to dumping sites. In the composition of waste production, there is an indication that the organic wastes hold the highest percentile of about $65 \%$ of the entire waste generated.

\subsection{Types and Sources of Solid Waste Generation}

The principal sources of solid waste include residential or households, commercial, institutional, construction and industrial wastes. However, a comprehensive example of the sources and types of solid waste presented by the UNESCAP (2012), is not different from the territorial boundary of the city Accra-Ghana. This is shown in table (2) below.

Table 1: Types and Sources of Solid Waste in the Study Area

\begin{tabular}{|c|c|c|}
\hline Source & Waste generators & Dxample of solid wastes \\
\hline Residential & Single and large family settings & $\begin{array}{l}\text { Waste generated from food, polythene } \\
\text { bags, electric cables, consumer electronic } \\
\text { appliances, waste from back yards, paper, } \\
\text { textiles, metals, glass etc }\end{array}$ \\
\hline Commercial & $\begin{array}{l}\text { Business buildings, guest } \\
\text { houses, trade areas including } \\
\text { stores and markets. }\end{array}$ & $\begin{array}{l}\text { Paper, cardboard, plastics, wood, organic } \\
\text { wastes, glass, metals, special wastes, } \\
\text { hazardous wastes }\end{array}$ \\
\hline $\begin{array}{l}\text { Construction } \\
\text { demolition }\end{array}$ & $\begin{array}{l}\text { Road construction and repairs, } \\
\text { New building areas and } \\
\text { renovation areas. }\end{array}$ & $\begin{array}{l}\text { metal waste, waste from concreate } \\
\text { mixture, waste from wood cutting, } \\
\text { filth waste }\end{array}$ \\
\hline Industrial & $\begin{array}{l}\text { Light and heavy } \\
\text { manufacturing, construction } \\
\text { areas, power generation and } \\
\text { chemical plants. }\end{array}$ & $\begin{array}{l}\text { packaging, food wastes, construction and } \\
\text { demolition materials, hazardous wastes, } \\
\text { ashes, special wastes, scrap metals }\end{array}$ \\
\hline Institutional & $\begin{array}{l}\text { Schools, government centre, } \\
\text { hospitals and Prisons. }\end{array}$ & $\begin{array}{l}\text { Paper, cardboard, plastics, wood, food } \\
\text { wastes, glass, metals, special wastes, } \\
\text { hazardous wastes }\end{array}$ \\
\hline Agriculture & $\begin{array}{l}\text { Farming area, gardens, } \\
\text { vineyards and crops }\end{array}$ & $\begin{array}{l}\text { Spoilt food wastes and hazardous wastes } \\
\text { like pesticides. }\end{array}$ \\
\hline Process(manufacturing) & $\begin{array}{l}\text { Heavy and light industrial } \\
\text { manufacturing, petroleum and } \\
\text { gas refineries, paint and } \\
\text { chemical plants, power plants, } \\
\text { mineral mining and processing }\end{array}$ & $\begin{array}{l}\text { Industrial process wastes, scrap } \\
\text { materials, slay, stakeouts etc. }\end{array}$ \\
\hline
\end{tabular}

Source: UNESCAP, (2012) 


\subsection{Methods of Solid Waste Collection and Disposal}

The services of waste collection may be on a relatively small scale, providing primary collection to local neighbourhoods, or on a larger scale, providing either secondary collection or an integrated collection service across the city. In the collection of solid waste and disposal, the main types of vehicles currently used by the AMA are compaction and skip trucks. The wastes are taken from its source by road directly to the landfill sites(Anomanyo E.D, 2004).

According to Anomanyo E.D (2004), solid waste collection in the study area is both a franchise and contract basis. In his explanation, franchise involves a house to house collection (known as block collection) in high income residential areas while the contractors charge the households some fees based on a weekly frequency. However, at the initial stage, the contractors distribute recycling containers to these households at no charge while the latter is charged base on the services rendered to the customers. The contractors then pay a fee known as a tipping fee to the AMA for usingtheir dumping sites. Korfmacher, K. S. (1997) also share the same scenario by attesting that residents rely on the services their providers for disposing of their waste. In this system, a collection vehicle travels a scheduled route, stopping periodically for residents to bring their refuse.

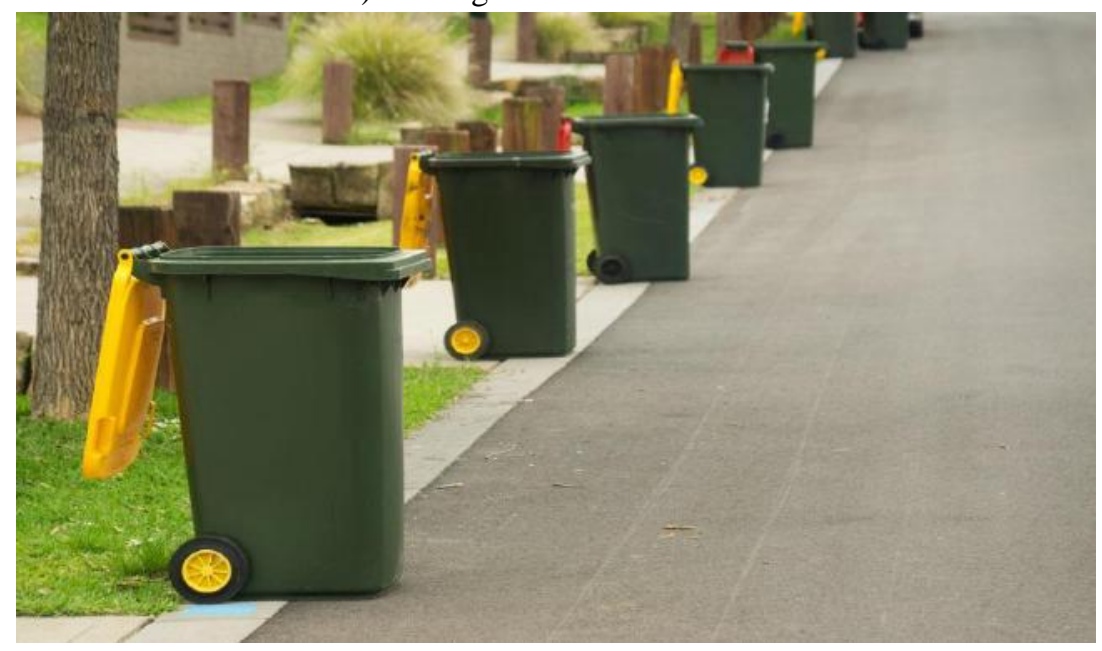

Fig.1: Block Collection in High Income Area

Source: trendmap.com, retrieved on $24^{\text {th }}$ May 2019

The contract aspect has to do with the AMA paying contractors to perform both block and communal container collection activities. As indicated above, the block collection takes place in high and middle-income areas with low population density and access to good roads. According to the study conducted by Anomanyo (2004), only 75 percent of the solid waste generated is collected and disposed of in these areas.

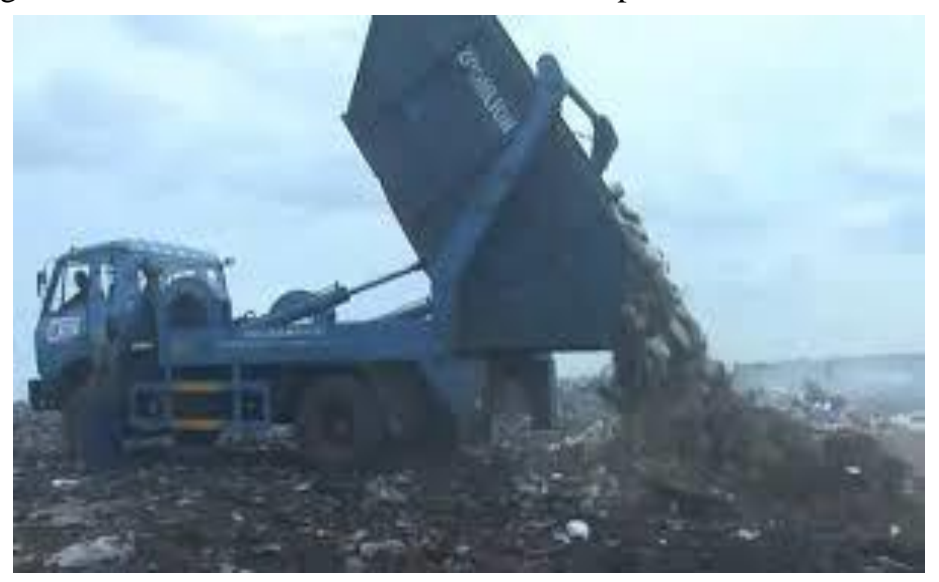

Fig.2: A Skip Truck Discharging Solid Waste Materials

Source: disposalknowhow.com, retrieved on $24^{\text {th }}$ May 2019. 
In high population density and low-income areas like Nima and James town, contractors use central communal containers for the collection of waste. Market areas are also part of this arrangement where people around the catchment area deposit their waste in communal containers and the frequency of collection is normally done by daily routine. However, waste generators do not pay any user fee. Also, in low-income areas, some of the waste generated by households are either buried or burnt.

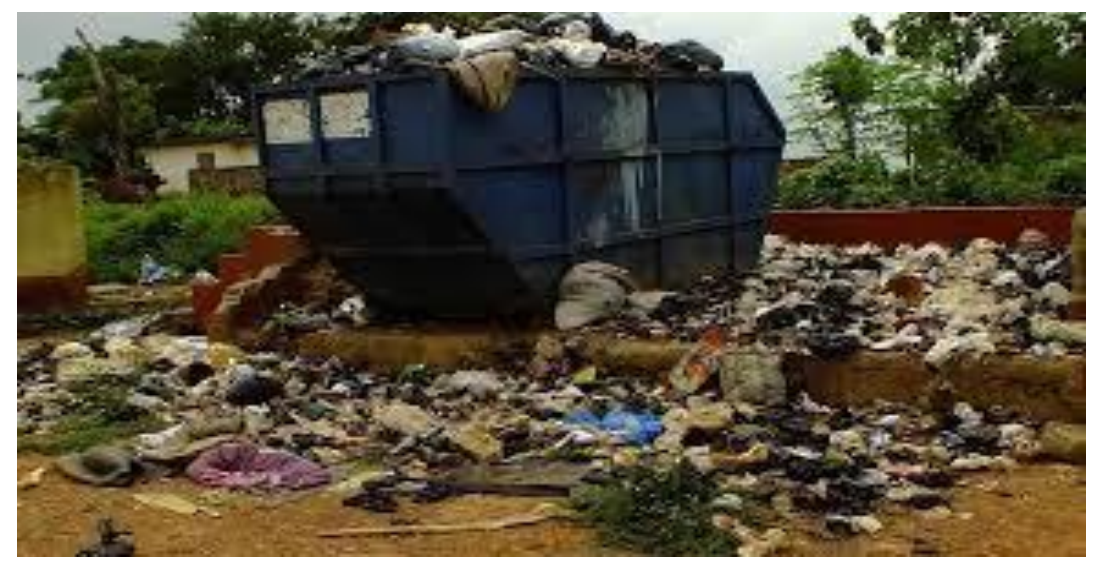

Fig.3: A Communal Container filled with Solid Waste Materials

Source: ghananewsprime.com, retrieved on $24^{\text {th }}$ May 2019.

\subsection{Solid Waste Management Policy and Legal Framework in Ghana}

As indicated by Saldeva, M. (2007), the Methodology for PAC gave their definition for policy as "game-plan or inaction embraced by the Government to address a given issue or interrelated arrangement of issues, or the manner by which the strategies for accomplishing the set objectives are resolved". So also, they defined the term "policy" as "intentional activity of Government that allows for a consequential adjustment or impacts the general public or economy outside the administration". It includes, but it is not limited to, taxation, regulation, expenditures, information, statements, legal requirements, and legal prohibitions.

The blueprint of policies for Ghana and that of the AMA appears very benign for the management of waste. However, in practical terms, these policies have failed to achieve the ultimate goal as a result of lack of clear definition of policies and implementation, lack of enforcement, lack of coordination and monitoring among others.

The Local Government Act (1994), Act 462 and the ESP of 1999 outline the policies and the legal framework guiding SWM in Ghana. However, implementation of the policy had many errors that consequently affected the goal of the policy for achieving sustainable SWM targets. In the year 2010, the policy was reviewed and amended by the policymakers to address and prevent future failures of the policies (Owusu-Sekyere, Bagah, \& Quansah, 2015). The reformation of the policy enhanced the priorities for development in both the national and international context especially a reflection in the Ghana Poverty Reduction Strategy, the New Partnership for African Development (NEPAD) and the Millennium Development Goals.

Under the auspices of the Ministry of Environment and Science, Ghana, therefore, established the Environmental Protection Agency in 1994 and created the environmental legislation which basically made up of the Environmental Protection Act 490 and Environmental Assessment Regulation LI 1652, however, Environmental Assessment procedure is the main instrumental tool for SWM(OwusuSekyere, Bagah, \& Quansah, 2015). Among all other things, the policy states that the disposal of solid waste must be consonant with standards and procedures directed by the EPA and any other regulatory agencies. It the overall responsibility of the Ministry of Local Government and Rural Development involving the Metropolitans, Municipalities and District Assemblies (MMDAs) to manage domestic solid waste although the regulatory power is invested in the EPA. Through the facilitation of the Waste Management Department (WMD) and Environmental Health and Sanitation Unit, the MMDAs, therefore, aid in the collection and final disposal of waste. The figure below therefore shows the institutional arrangements for SWM. 


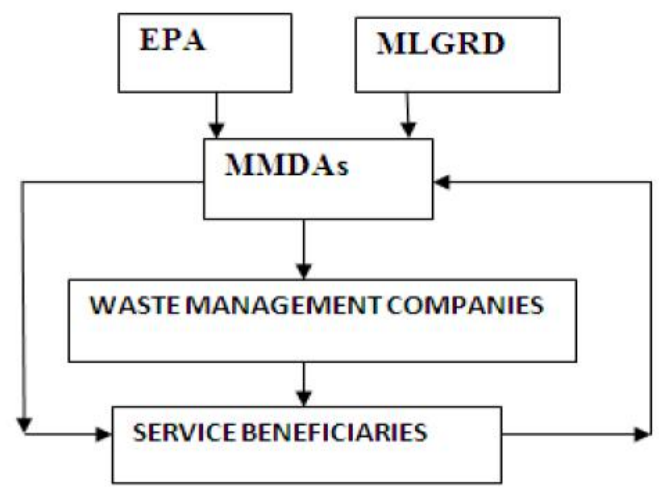

Fig.4: Institutional Arrangements for Solid Waste Management

Source: (Owusu-Sekyere, Bagah, \& Quansah, 2015)

\subsection{Impacts of Improper Solid Waste Management on Human Health, Animals and Aquatic Life}

There are potential risks to the environment as well as the health of biotic organisms including humans, animals and aquatic species from improper handling of solid wastes. The result of all the types of pollution such as air, soil and water strongly correlate with improper SWM. In most populated urban areas, solid waste materials block drains, emanating from indiscriminate dumping of waste causing seasonal flooding's, stagnant water bodies for the breeding of insects like mosquitoes (Bavel \& Reher, 1999).

Majority of solid wastes are disposed on the land in open dumps. Disposal of solid waste on the land without careful planning and management can bringmany dangers to the environment and human health. The environment should be catered for and less populated at all cost. This means that waste should be managed in such a way that the impacts on the environment will be minimal (US Environmental Protection Agency 2006).

Open dumpsites contribute to one of the major problems to the deterioration of the environment which in turn pollute the air that people inhale. Dumpsites emit unpleasant odours as well as smoke that may cause respiratory diseases to people living around (Marshal 1995). Issues on health and safety also arise from improper SWM. Organic waste in the form of human faecal matter is usually common in municipal solid waste, especially in low income areas. However, insects and rodents that set on this faecal matter can spread diseases like cholera and dengue fever (Bavel \& Reher, 1999).

According to Wrensch et al., (1990), during active landfill site operation, dumpsites maybe a source of airborne chemical contamination through the expel of gases and particles as well as chemicals coming from dust. Lack of proper treatment of dumpsites may lead to soil and underground water contamination, especially organic solid waste materials containing filth saturated water content seeps through the soil and contaminates the water table. Heavy downpour also contaminates both the underground and running water (rivers, lagoons, lakes etc), especially through the process of washing away solid waste particles into these streams, some of which seeps the dirty particles into the underground water which have a negative repercussion on the health of people living in around the dumpsites. Another instance given by Wrensh (1990) shows that in some dumpsites, unstable (volatile) organic chemicals have been detected in odour air of nearby homes around the dumpsites. Bavel \& Reher (1999) also found that using water contaminated by solid waste for bathing, irrigation purposes, and drinking can expose individuals to many diseases.

Songsore and McGranahan (1993) found that as a result of unsanitary conditions in many of the study area (Accra), the prevalence of parasites, cholera, diarrhoea and malaria has also increased extensively. The out-patient department (OPD) of many facilities in Accra also reported similar cases of infectious diseases especially among residents in and around slums areas, landfill sites including malaria, intestinal worms, and upper respiratory infections. The Environmental Protection Agency (2002) added that in most parts of the Accra, drains and gutters blocked by solid waste materials have created stagnated waters acting as habitat or breeding grounds for mosquitoes, which later transmits common diseases like malaria and fever to many residents.

\subsection{Empirical Part: Solid Waste Management in Accra}

Solid waste collection and disposal is in the hands of the Accra Metropolitan Assembly's Waste Management Department (WMD). Thus, the department is responsible for managing solid waste within the jurisdiction and 
confines of the area including the management of the landfill sites in Mallam, Djanman and Oblogo.

\subsection{Conceptual Framework of the Study}

Figure 5 gives a summary representation of the SWM framework and its impacts on the livelihoods of people. The socio-economic activities and the livelihoods of people can be realized through the medium of commerce, domestic, industry and agriculture which eventually becomes the major ways and means of solid waste generation. Socio-economic activities are most influenced by the rate of population growth. Thus, the higher the rate of population growth, the higher the level of urbanization and growth of socio-economic activities which causes an uncontrolled generation of heaps of waste in many towns and cities. Low revenues for city councils, high SWM expenditures, inadequate logistics, poor general attitude for handling solid waste, inadequate public education, weak sanitation policies and laws, among others are the attributable factors for poor SWM (Ampofo, Soyelle, \& Abanyie, 2016).

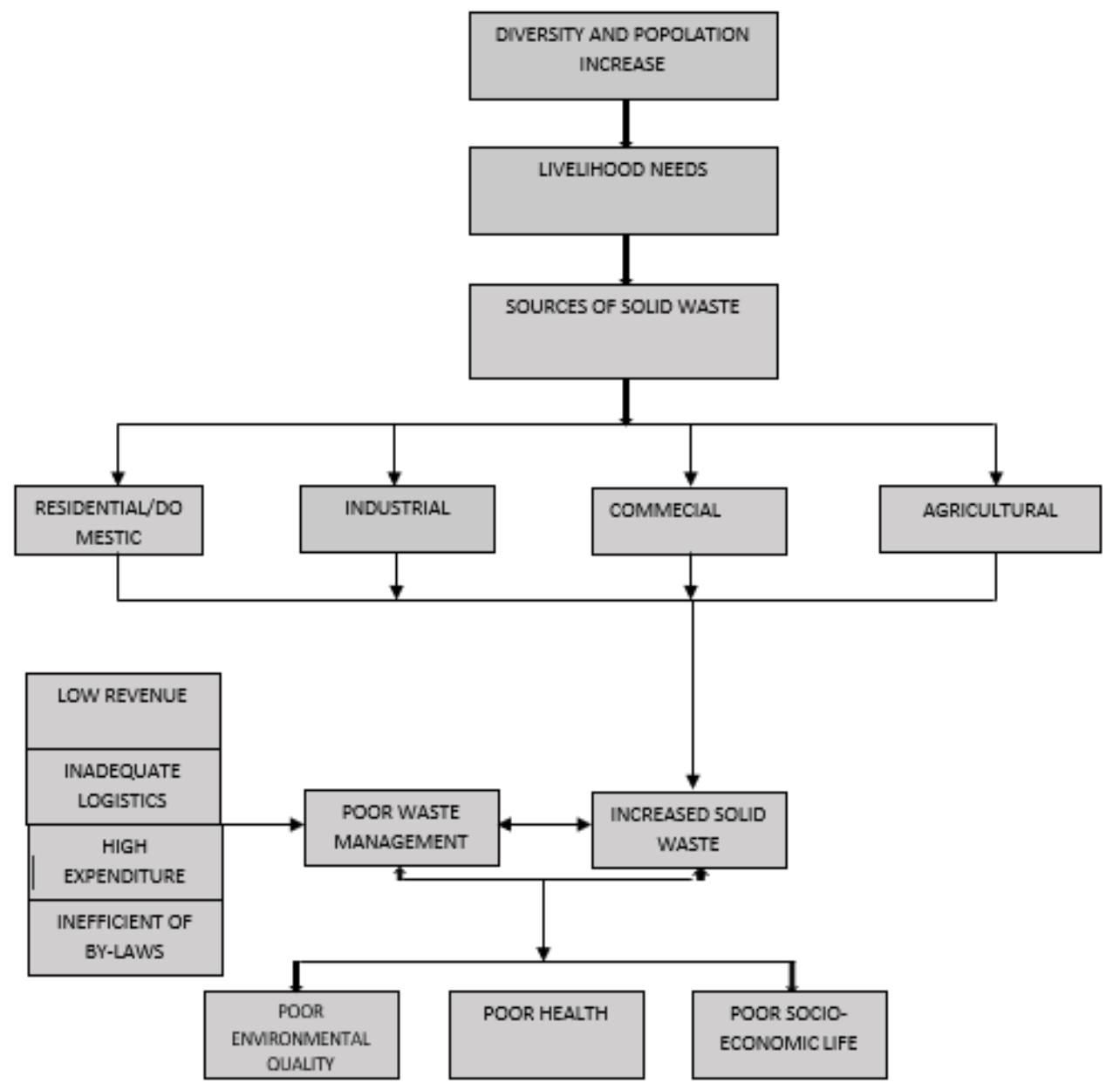

Fig.5: Conceptual Framework of Impact of Sustainable Solid Waste. Source: (Ampofo, Soyelle, \& Abanyie, 2016)

\subsection{Roles of Public Administration (AMA) in the Solid Waste Management}

Good SWMplays an important role in the achievement of sustainable development. The entire sectors of the economy suffer when waste is poorly managed, as such, the impacts that may result from poor SWM include; poor health on the part of the citizens, land destruction, deterioration of the ecosystem involving the marine and coastal land, and most of all diminishes the gains from tourism and fisheries. Governance is also about responsibility, expressed through various legal and financial obligations, but also through a sense of 'ownership' of waste-related issues, which translates into involvement and care about the cleanliness of the open spaces in the community as well as protection of the broader environment and natural resources. The latter means that good waste governance goes beyond street cleaning and waste handling into the 
realms of production and consumption (Wilson et al., 2015). Governmental institutions are established and given a specific mandate by law, as one of the instruments through which a nation's policy goals are defined and reached. For an effective waste solid management system, a strong, robust and transparent institutional framework is essential, within which institutions take various roles at different levels of government, from national to local. At the national level, the main role of the government and its institutions is that of policy maker and legislator, which includes strategic planning and preparation of policies, and their translation into legislation. Institutions deploy various participatory governance processes so as to benefit from the interaction with other societal actors in which they can contribute their knowledge, insights, queries and concerns on stakeholders.It has been documented that proper SWM can help promote sustainable development if critical attention is given, especially in the provision of finance, logistics, and effective management, however, due to some challenges like poor or lack of logistics, limited recycling plants, lack of funding for the management of waste, poor attitude and practices on the part of many citizens, lack enforcement and regulations and the obstacles of moving waste from one geographical area to another contribute largely to poor or insufficient solid waste management.

Dijk et al. (2017), noted that SWM in Ghana is the sole responsibility of the decentralized local government assemblies across the country. The assemblies represent the national government within their jurisdiction for the SWM. However, the local government assemblies across the country have strong backing from the Ghana Local Government Act 1993 (Act 462). This legal support gives them the mandatory power to enforce by-laws to guide and control SWM, sanitation, public cleaning and mitigate the act of indiscriminate disposal of waste in the city. The roles exercise by the public administration (national and local government) in Ghana, are discussed as follows;

National government; the central or the national government is responsible for the establishment of the institutional and legal framework. The national government provide support and ensure that local governments have the authority, power and capacity to effectively and efficiently manage solid waste. Schubeler, Wehrle and Christen (1996), added that the processes involved in the establishment of the institutional framework are usually done without the local government being given the needed support to build capacity.

Local government; generally, the local government are responsible for solid waste collection and disposal services. The obligation of upholding by-laws, controlling SWM activities and mobilizing funds and effective administration running for SWM as a responsibility of the local government is conferred by higher government authorities. Schubeler, Wehrle and Christen (1996) also made an elaborative relationship between the local government and the private firms by attesting that in a situation whereby a private company is contracted to provide solid waste services, the local government is mandated to regulate and control the activities such private firm or company.

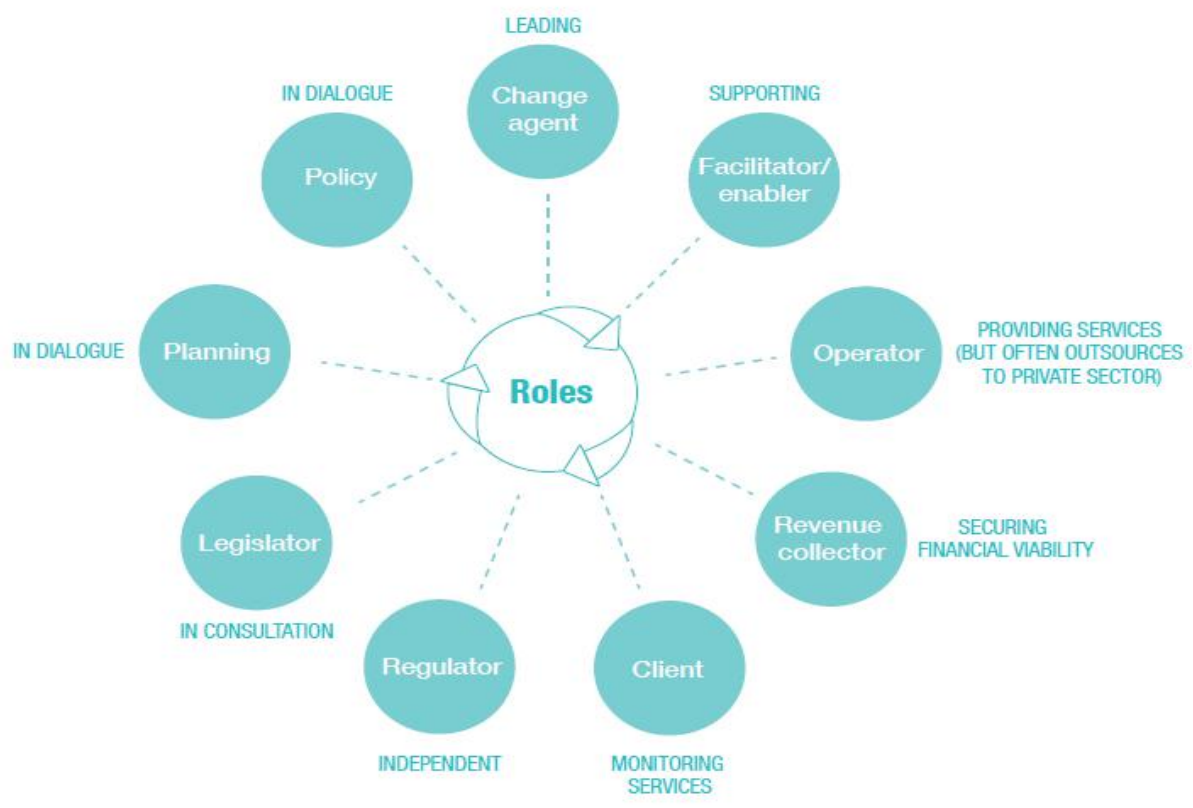

Fig.6: The Role of Public Administration (Government Institutions) in Waste Management

Source: United Nations Environment Programme, 2015 


\subsection{Management Process of Solid Waste}

The Accra metropolitan through government intervention has commissioned a series of waste management plants including the recent Accra Waste Recovery Recycle plant and other waste transfer stations. However, coupled with some challenges like unstable power supply and limited capacities, majority of the waste generated end up at the landfill sites (retrieved from myjoyonline.com, on $25^{\text {th }}$ May 2019). Ghana and for that matter, Accra has a complex management process in terms of SWM. However, due to the challenges mentioned above, ranging from the unstable power supply and lack of proper management and maintenance, the most commonly used management process is shown in figure (8) below.

Hypothesis 1:Inefficient enforcement of by-laws plays a significant role for poor solid waste management.

Hypothesis 2: There is no relationship between distance of solid waste dumpsites and spread of diseases among residents.

Hypothesis 3:Proper methods of solid waste disposal plays a major role for sustainable solid waste management,

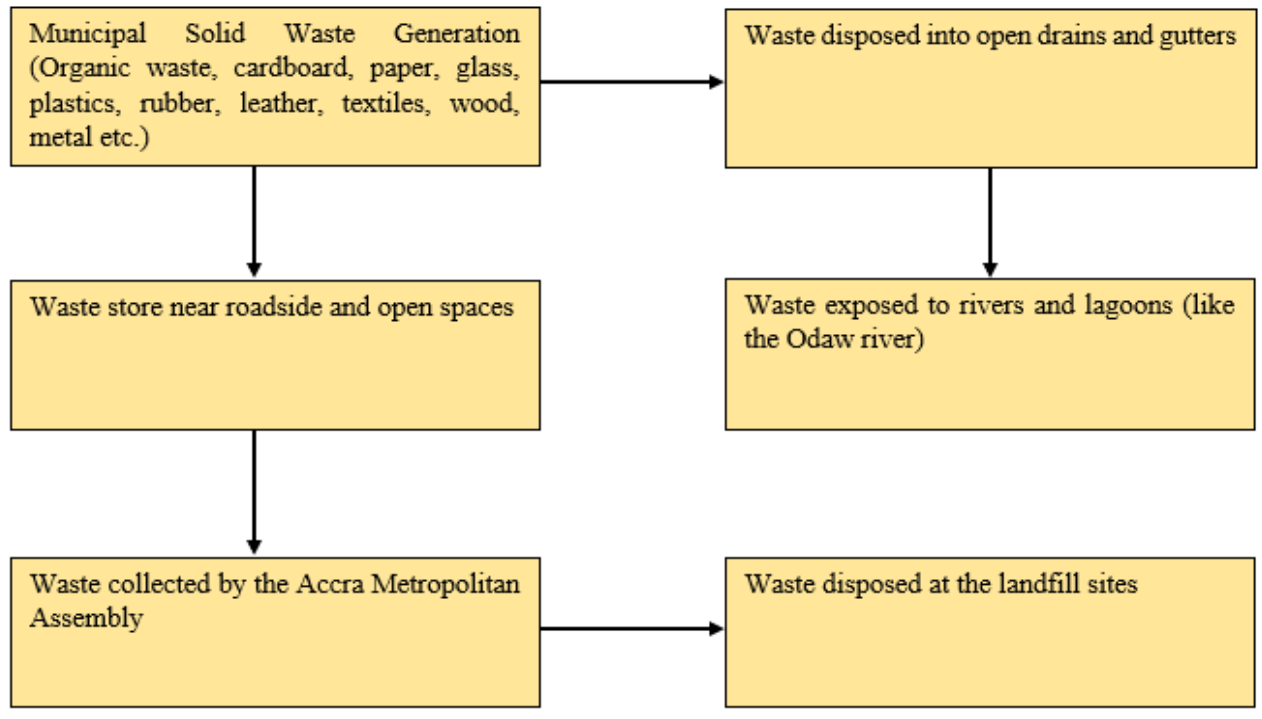

Fig.7: Common Management Process of Solid Waste

Source: Developed by the Author

\section{DATA ANALYSIS AND DISCUSSION OF THE FINDINGS}

The by-products of human activities and consumptions and its subsequent consequences become more concentrated following the movement of people into towns and cities globally. The impact of urbanization has also overrun spaces that could possibly be used to manage solid waste. However, it has become important for transporting waste to more distant areas and zones. It is, therefore, necessary for inter-municipal cooperation, under a different local administration to deal with solid waste which is far from its origin (Wilson et al. 2015). The profile of the study reveals an observed increase in the human population from time-time with the dangers of worsening the current situation of uncontrolled solid waste in the study area. However, there can be so many direct and indirect benefits if solid waste is properly managed by public administrators or government institutions (programmes designed to managed solid waste) to enhance sustainable waste management in the area. In the developing world, 'waste' is still largely an urban phenomenon. From this note, the questions and the discussions are structured as such;

1. What are the policies governing solid manage waste practices in the Accra Metropolitan Area of Ghana?

The findings revealed several policies governing SWM in Ghana which include the Environmental Sanitation Policy of 1999 which had the legal backing from the Local Government Act (1994), Act 464. However, the findings also revealed that this policy had many flaws in its implementation until it was reviewed and amended in 2010 which saw a significant reflection for structural change in the GPRS, the NEPAD and the MDGs at the national and international level. Another policy is the Environmental Assessment Regulation LI 1652 which had a legal support from the Environmental Protection Agency Act 490 which spelt out that the Environmental Assessment Regulation (EAR), is the main tool and also states that disposal of solid waste should be in relation to standards and 
procedures for SWM prescribed by the EPA and other regulatory bodies. By and by, the findings revealed that there are inefficiencies in the policies. Owusu-Sekyere, Bagah, \& Quansah (2015, pp. 53-54), observed that policies governing SWM are inadequate and even have become outdated. They are added that the obsolete nature of the SWM policies are scary to the extent that it appears to be protecting the environment and the people yet fooling them and which may rather expose them involuntary.

2. What are the types and sources of waste as well as methods of waste disposable in the study area?

The sources and types of solid waste generation primarily originate from domestic, commercial, institutional, constructional sites and industrial activities. These wastes include; plastics, metals, paper, organic wastes, glass, textiles, wood wastes, agricultural wastes and other forms of solid wastes. A study conducted by Kramer et al. (1994) cited by Boadi, K. O., \& Kuitunen, M. (2003) shows that organic wastes constitute more than 70 per cent of all waste generated in the Accra metropolitan area, inert materials also accounted for 10.5 per cent, paper wastes constituted for 6.6 per cent, textiles and metals accounted for 2.2 and 2.1 respectively while glass and other forms of waste equated to 1.5 per cent and 0.7 per cent.

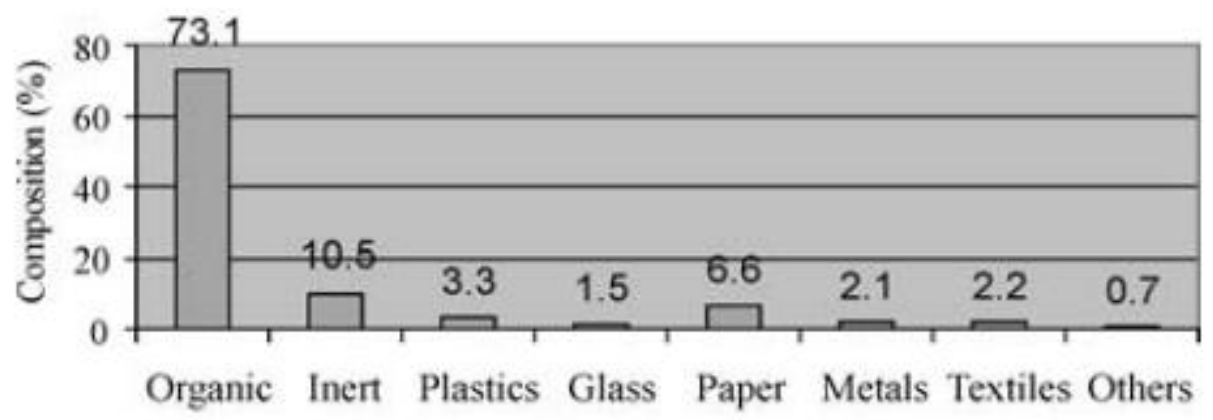

Fig.8: Components of Solid Waste Materials

Source: Kramer et al. (1994)

The Waste Management Department (WMD) of the AMA (2010 cited by Boamah A. Linda 2010) also revealed that on a daily basis, the city generates about 2200 tonnes of solid waste. By segregating these wastes into types, organic waste constitutes $65 \%, 6 \%$ for paper, $6 \%$ for plastic, $3 \%$ for glass, $2.5 \%$ accounts for metals while $1.7 \%$ and $15.8 \%$ accounts for both textiles and inert materials respectively.

The methods of solid waste collection and disposal vary from one geographical area to another. Generally, in high and middle-income areas, waste collection is done by block collection method. In this case, the solid waste service providers move from house to house to collect these wastes while in low income areas and public spaces like markets, central communal containers are used for solid waste collection and disposal. Again, in most low- income areas, solid waste burning is very common due to limited access to waste facilities. Areas isolated from the main town also dispose of their waste in open pits, however, in these areas, residents cover the pits with either sand or burn the waste from digging new pits especially it the pits are filled with waste (Boadi, K. O., \& Kuitunen, M. 2003).

It is very important to note that despite all these waste collection methods, some proportion of the waste is left uncollected. According to the CCAMSWI (2014) reported that waste collection in the AMA is limited. It estimated that only 40 per cent of the households in the city have recycling or waste collections bins. However, the 60 per cent of the waste is indiscriminately dumped in informal areas like abandoned sites including quarry areas, dig holes, etc. 


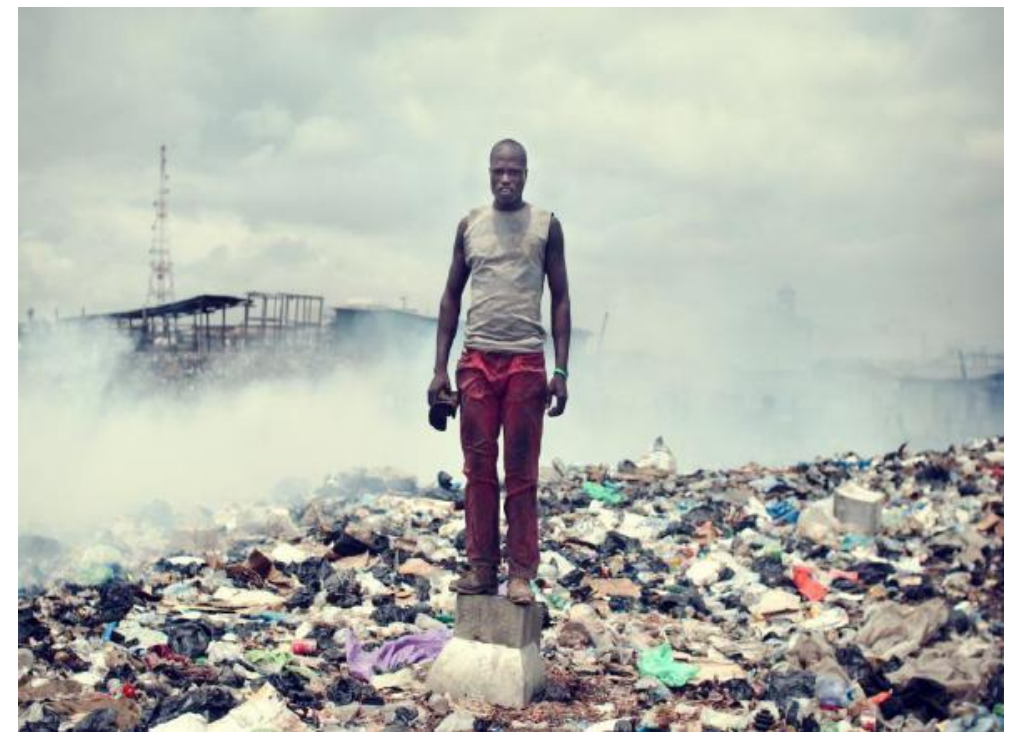

Fig.9: Landfill Site in Accra

Source: http://kevin-mcelvaney.com/portfoliolagbogbloshiel. Retrieved on $6^{\text {th }}$ June 2019.

3. What are the impacts of improper waste management on the health of people in the study area?

To answer to this question, a hypothesis was tested as to whether improper solid waste management has a significant influence on the health of is tested. Ho: there is no relationship between distance of solid waste dumpsites and spread of diseases among residents. Ha: there is a strong relationship between distance of solid waste dumpsites and the spread of diseases among residents. Poor solid waste management has a negative effect on the three main media of nature namely, air, water and the environment (land). The damage to these important media consequently turns to affect the health of humans and living organisms including species in the water bodies, biodiversity and other species alike. The impact of environmental problems and its subsequent effects on human health, economic and other welfare losses can be inherently attributed to poor or improper SWM (Kolsch, F., \& Ziehmann, G. 2004 cited by Bekoe-Nketia, 2015).

As reported by the Out-Patient-Department (OPD) unit of most facilities in Accra, common infectious diseases among people living in slum areas and close to landfill sites include malaria, intestinal worms, dengue fever and upper respiratory infections (Songsore \& McGranahan 1993 cited by Anomanyo E.D 2004). The current situation in the area shows that proper SWM delivery is very limited, only 40 per cent of the entire households in the city have access to proper solid waste services (Climate and Clean Air Coalition Municipal Solid Waste Initiative 2014). This situation has therefore forced most residents to either bury or burn waste. In some cases, open places, bushes, drains, rivers become the only option for residents for disposing of waste, especially at night where people cannot see them. These poor attitude and practices raise several dangers to the health of many citizens as well as the spread of poverty. Bekoe-Nketia (2015) found that primary effect of improper solid waste management within most communities in Ghana including Accra is air pollution and unpleasant odour that many residents inhale from decomposed rotten materials and the smoke that comes out from dumpsites especially when burning solid waste materials. Kolsch, F., \& Ziehmann, G. (2004), also confirms that the major cause of air pollution is due to the burning of solid waste materials at dumpsites, causing illness and reducing visibility, causing explosions of bottles and cans, making dumping sites dangerously insecure and probable spread of poverty. Alternatively, AlYaqout et al, (2002)and Vidanaarachchi et al. (2005) cited by Bekoe-Nketia (2015), confirm that one of the dangerous causes of air pollution is solid waste, therefore to enhance environmental quality through sustainable SWM it is very important to ameliorate the situation of improper solid waste management.

A study steered by Suleman (2016) reveals that there is a strong relationship between improper solid waste management and its subsequent consequences on the health of people. This was confirmed by a chi test results where the Pearson chi-value of 0.017 with a degree of freedom of 2 and a tested significance level of 0.05 in the table (3) below. 
Table 2: Pearson Test for Improper Solid Waste Disposal and Impact on the Health of People

\begin{tabular}{|l|l|l|l|}
\hline & Value & Df & Asymp. Sig. (2-sided) \\
\hline Pearson Chi-Square & $8.129^{\mathrm{a}}$ & 2 & 0.017 \\
\hline Likelihood Ratio & 8.719 & 2 & 0.013 \\
\hline $\begin{array}{l}\text { Linear-by-Linear } \\
\text { Association }\end{array}$ & 5.684 & 1 & 0.017 \\
\hline N of Valid Cases & 144 & & \\
\hline
\end{tabular}

Source: Suleman, Y. (2016),https://doi.org/10.4172/2165-784X.1000202, retrieved on June 6, 2019

However, from this result, the null hypothesis is accepted, since the Pearson correlation test confirms that there is a strong relationship between distance of solid waste dumpsite and the spread of diseases among residents. Further, the study of Suleman (2016) revealed that residents who stay closer to solid waste dumping sites stand the risk of contracting infectious diseases. However, the prevalence of disease acquisition reduces when the distance between residents and the dumping sites become wider. The study showed that 75 per cent of respondents who are close to the dumping sites had cases of malaria, while 2 per cent of the households relative far from the dumping sites had malaria cases. Alternatively, the findings revealed that 72 per cent and 75 per cent of the respondents whose houses are located close to the dumping sites had cases of skin infections and typhoid fever respectively while cases among residents far from the dumping sites were very minuet and this shown in table (4) below;

Table 3: Some Related Diseases contracted from Landfill Sites

\begin{tabular}{|l|l|l|}
\hline Category & Frequency & Percent \\
\hline Cholera & 8 & $5 \%$ \\
\hline Malaria & 105 & $71 \%$ \\
\hline Typhoid fever & 15 & $10 \%$ \\
\hline Skin infections & 20 & $14 \%$ \\
\hline Total & 148 & $100 \%$ \\
\hline
\end{tabular}

Source: Suleman, Y. (2016),https://doi.org/10.4172/2165-784X.1000202, retrieved on June 6, 2019

\section{CONCLUSION AND RECOMMENDATION}

According to Wilson et al, (2015) management of MSW is a key responsibility of the government to protect public health and theenvironment for all the citizens. SWM in the Accra metropolis not up to standard, as logistical equipment remains a key challenge in most part of the city especially low-income areas, hence needs immediate intervention by the government and other nongovernmental bodies (Boadi and Kuitunen, 2003).

Challenges facing private sector involvement in the management of solid waste must be addressed by the government such as granting soft loans to procure equipment and also hire qualified personnel to deal with the problem of solid waste management. Private sector involvement and participation in SWM delivery must be done through a competitive arrangement and concerns for solid waste collection and disposal and dumping sites ISSN: 2456-1878 operations in order to improve environmental accountability(Bartone and Leitman, 1994).

There should also be the full involvement of informal waste collectors including waste carriers, waste recyclers, waste hunters (scavengers) and waste pickers in the SWM process to enhance the benefits of their contributions for sustainable city development. To enhance strategic solid waste management in Accra, there must be the involvement the active participation of those affected by solid waste problems, as well as those who regulate policies and implementation instruments, and those who possess relevant information and expertise (Bartone and Leitman, 1994). Decision making involving communities and especially the marginalized in society will augment self-confidence for mobilizing efforts and local resources for environmental management, particularly in low income areas. Also, more efforts must be directed at upgrading 
local SWM infrastructure and services. This must include the provision of adequate facilities for waste management and requiring users to pay for the full cost of the service in order to enhance the efficiency and coverage of service delivery (Bartone and Leitman, 1994).Institutional capacity in the field of planning must be strengthened to effectively deal with the environmental and sanitation problems facing the city. For efficient waste management, every house in the city must be accessible by road, and this calls for proper layouts in the city (Boadi \& Kuitunen, 2003). Capacity should also be strengthened in the area of poverty alleviation to enable the poor to afford the cost of environmental services. The metropolitan authorities must enact and improve the necessary policy measures to attract local and foreigndirect investments. These include institutional policies aimed at ensuring the safety of investments, removing bureaucratic bottlenecks to attract investors creating free trade zones and. City authorities must also encourage local investment for sustainable solid waste management through the provision of soft loans to small-scale businesses to expand their activities and also encourage local entrepreneurs to form co-operative organizations to mobilize funds for investment in sustainable SWM.

Lastly, attention must be geared towards local capacity in data collection and analysis in solid waste management. The availability of such data would be beneficial to determine and select the appropriate technology for the management of solid waste in Accra. Also, a periodic citywide survey on SWM must be undertaken by Accra Waste Management Department (AWMD) that will provide complete and dependable information on the amount and the nature (different types of solid waste) that are generated on average basis so as to come out with a suitable and sustainable approach to treat and dispose such wastes.

\section{REFERENCES}

[1] Ampofo, S., Soyelle, J., \& Abanyie, S. K. (2016). The Negative Impacts of Poor Municipal Solid Waste Management on Livelihoods in Walewale Township, West Mamprusi District, Ghana: A Social Survey and Assessment. 11. www.iiste.org

[2] Anomanyo, E. D. (2004). Integration of municipal solid waste management in Accra (Ghana): Bioreactor treatment technology as an integral part of the management process. Lund University, Sweden.

[3] Bartone, C., \& Leitman, J. (1994). Towards environmental strategies for cities, urban infrastructure notes, urban No. UE-11. Washington, DC: World Bank.

[4] Bavel, J. V., \& Reher, D. S. (1999). What we know and what we need to know about the baby boom. 40.
[5] Bekoe-Nketia, F. (2015). SOLID WASTE HERE AND THERE: THE EFFECTS ON PUBLIC HEALTH AND THE ENVIRONMENT. 17(2), 7.

[6] Benneh, G., Songsore, J., Nabila, J. S., Amuzu, A. T., Tutu, K. A., Yangyuoru, Y., \& McGranahan, G. (1993). Environmental problems and the urban household in the Greater Accra Metropolitan Area (GAMA)Ghana. Stockholm Environment Institute, Stockholm.

[7] Boadi, K. O., \& Kuitunen, M. (2003). Municipal Solid Waste Management in the AccraMetropolitan Area, Ghana. The Environmentalist, 23(3), 211218.https://doi.org/10.1023/B:ENVR.0000017283.09117 .20

[8] Chang, N. B. (2015). Sustainable solid waste management: a system engineering approach. John Wiley \& Sons.

[9] Chazan, D. (2002), "A World drowning in litter", BBC. Retrieved from full text database", available from http://news.bbc.co.uk/2/hi/Europe/1849302, $2^{\text {nd }}$ December 2018. DC

[10] Dijk, M. P. van, Edelenbos, J., \& Rooijen, K. van (Eds.). (2017). Urban Governance in the Realm of Complexity. The Schumacher Centre, Bourton on Dunsmore, Rugby, Warwickshire: Practical Action Publishing Ltd.https://doi.org/10.3362/9781780449685

[11] Heller, L., \& Catapreta, C. A. A. (2003). Solid waste disposal in urban areas and health - the case of Belo Horizonte, Brazil. Waste Management \& Research, 21(6), 549-556. https://doi.org/10.1177/0734242X0302100607

[12] Kolsch, F., \& Ziehmann, G. (2004). Landfill stability-risks and challenges. Waste Management World, 55-60.

[13] Korfmacher, K. S. (1997). Solid waste collection systems in developing urban areas of South Africa: An overview and case study. Waste Management \& Research, 15(5), 477-494.https://doi.org/10.1177/0734242X9701500504

[14] Kwawe, B.D. (1995), "Culture of waste handling: Experience of a rural community", Journal of Asian and African Studies, Vol. xxx, No. 1-2.

[15] Lyse, O. (2003). Waste disposal haunts cities. The Times of Zambia (Ndola). Retrieved from Allafrica.com/stories on $26^{\mathrm{TH}}$ April,2019.

[16] Marshal, E. (1995). Analytic study to evaluate associations between dumpsites and birth effects. ATSDR CO. LTD: Atlanta.

[17] Owusu-Sekyere, E., Bagah, D. A., \& Quansah, J. Y. D. (2015). The Urban Solid Waste Management Conundrum in Ghana: Will It Ever End?http://hdl.handle.net/123456789/1417

[18] Saldeva, M. (2007.). POLICY DEVELOPMENT HANDBOOK. 100.http://www.vlada.mk/

[19] Skenderovic, I., Kalac, B., \& Becirovic, S. (2015). Environmental pollution and waste management. Balkan Journal of Health Science, 3(1).https://www.researchgate.net/publication/282 $\underline{278985}$

[20] Suleman, Y. (2016). Solid Waste Disposal and Community Health Implications in Ghana: Evidence from Sawaba, Asokore Mampong Municipal Assembly. Journal of Civil 
International Journal of Environment, Agriculture and Biotechnology, 5(6)

Nov-Dec, 2020 / Available: https://ijeab.com/

\& Environmental Engineering, 05(06). https://doi.org/10.4172/2165-784X.1000202

[21] UNCHS (1996), An Urbanizing world global reports on human settlements, Oxford University Press.

[22] UNESCAP, A. (2012). UNDP. (2013). Asia-Pacific aspirations: Perspectives for a post-2015 development agenda. Asia-Pacific MDGs Report, 13.

[23] Wilson, D. C., Rodic, L., Modak, P., Soos, R., Carpintero, A., Velis, K., ... \& Simonett, O. (2015). Global waste management outlook. UNEP,http://web.unep.org/ourplanet/september-

2015/unep-...

[24] Wrensch, M., Swan, S., Murphy, P. J., Lipscomb, J., Claxton, K., Epstein, D., \& Neutra, R. (1990). Hydrogeologic assessment of exposure to solventcontaminated drinking water: pregnancy outcomes in relation to exposure. Archives of Environmental Health: An International Journal, 45(4), 210216.https://doi.org/10.1080/00039896.1990.9940804 